\title{
Effect of methyltrimethoxysilane impregnation on the cell wall porosity and water vapour sorption of archaeological waterlogged oak
}

\author{
Magdalena Broda ${ }^{1}$ (D) . Simon F. Curling ${ }^{2}$ - Morwenna J. Spear ${ }^{2}$. \\ Callum A. S. Hill 3,4
}

Received: 7 November 2018 / Published online: 2 May 2019

(c) The Author(s) 2019

\begin{abstract}
This paper presents the water vapour sorption behaviour of degraded archaeological oak (Quercus robur L.) and the influence of methyltrimethoxysilane treatment on hygroscopicity. Wood samples (archaeological and undegraded recent oak) were treated with methyltrimethoxysilane using an oscillating pressure method. Moisture properties of the samples were determined using a dynamic vapour sorption system, and the surface area and porosity of treated and untreated waterlogged wood, previously dried using different methods, were characterised using a nitrogen sorption method. It was found that the silane modification resulted in a decrease in the equilibrium moisture content of archaeological oak samples from 23.7 to $19.4 \%$ for heartwood and from 23.3 to $10.0 \%$ for sapwood, respectively. After correction for silane content, however, the maximum equilibrium moisture content of the treated samples was $23.6 \%$ for heartwood and $21 \%$ for sapwood, which points rather at a bulking mechanism than chemical modification by silane. The results of the surface area and porosity measurements indicate that methyltrimethoxysilane is deposited in the cell wall and thus helps to preserve the microstructure of archaeological waterlogged wood.
\end{abstract}

Magdalena Broda

magdalena.broda@up.poznan.pl

1 Institute of Wood Chemical Technology, Faculty of Wood Technology, Poznań University of Life Sciences, ul. Wojska Polskiego 38/42, 60-637 Poznań, Poland

2 BioComposites Centre, Bangor University, Bangor, UK

3 InnoRenew CoE, Izola, Slovenia

4 Norwegian Institute of Bioeconomy Research (NIBIO), As, Norway 


\section{Introduction}

Archaeological waterlogged wood has a tendency to shrink and degrade on drying. This is known to relate to chemical and physical changes within the cell wall material. This paper sets out to investigate the porosity of the cell wall of waterlogged archaeological wood, and its influence on hygroscopicity, with the aim of increasing the understanding of the mechanisms of preservation available to the curator in preparing artefacts for storage, with a particular emphasis on silane treatments.

Wood cell walls have a porous structure with numerous void spaces of different size and shape. In sound wood, the largest pores in the cell wall are those of pit membranes $(20-100 \mathrm{~nm})$, followed by interfibrillar void spaces with a diameter range of $1 \mathrm{~nm}$ in dry wood to $1.2-10 \mathrm{~nm}$ in the swollen state, and finally, the smallest are transient cell wall capillaries that exist only when the cell wall is in the swollen state (0.4-100 nm according to various researchers) (Burr and Stamm 1956; Fengel and Wegener 1984; Nicholas 1973; Smulski and Cote 1984; Yin et al. 2015). As the porosity of the cell wall influences many physical and chemical wood properties, the "geometry" of the pores (volume, size, shape and connectivity) has been studied to understand processes such as wood-water relationships, the transfer of matter in wood, fibre shrinkage, mechanical properties, wood decay, chemical bleaching, pulping and modification of wood (e.g. Flournoy et al. 1991; Grönqvist et al. 2014; Hill and Papadopoulos 2001; Stone and Scallan 1968; Yin et al. 2015; Zauer et al. 2014). Others have considered porosity at a different length scale, including the cell lumina themselves (Pfriem et al. 2009; Plötze and Niemz 2011); however, this paper will consider only the cell wall porosity. Therefore, in the subsequent text, any use of the term porosity refers to cell wall porosity unless specifically stated.

In the case of waterlogged archaeological wood, though, due to its microbial degradation, the porosity of the cell wall takes on a different meaning. While low oxygen availability in wet environments reduces the number of potential wood degraders, decay by anaerobic microorganisms, such as soft-rot fungi, erosion and tunnelling bacteria, occurs, thus increasing cell wall porosity (Blanchette 2000, 2010; Björdal 2012). Soft-rot fungi initiate decay from the cell lumen and degrade polysaccharides in preference to lignin. Two distinct morphological forms of soft-rot decay are recognised: Type I creates characteristic cavities parallel to the direction of the cellulose microfibrils in the secondary cell wall (S2). The length of these cavities can reach ca. $40 \mu \mathrm{m}$, and their diameter ranges from 0.2 to $0.3 \mu \mathrm{m}$ in the early stage of decay (which corresponds to the diameter of the hyphae) to 3-5 $\mu \mathrm{m}$ in late stages of decay. In comparison, Type II soft-rot results in erosion of the whole secondary wall. The characteristic feature of soft-rot fungi is that they do not degrade the middle lamellae. Therefore, even in severely degraded wood, the lignin-rich skeleton of the middle lamellae remains well preserved helping the wood maintain its integrity under wet conditions (Björdal 2012; Blanchette 2000; Daniel 2014; Hale and Eaton 1986).

Erosion and tunnelling bacteria are similar in size $(1.5-2.0 \mu \mathrm{m}$ in length and $0.5 \mu \mathrm{m}$ in diameter), and they often co-attack the same wood cells. Similar to soft-rot, erosion bacteria can decompose cellulose and hemicelluloses leaving a 
coherent skeleton of middle lamellae. They initiate decay from the cell lumen, through the S3 layer towards the S2 region and strictly follow the long direction of the cellulose microfibrils, producing characteristic erosion channels. In comparison, tunnelling bacteria can metabolise a substrate that is rich in lignin and extractives and unlike erosion bacteria or soft-rot, they can cause direct penetration of the cell wall from both the surface of wood and the cell lumen. Moving in all directions, regardless of the microfibril orientation, they produce very thin branching and radiating decay patterns within the cell wall (Björdal 2012; Daniel 2014; Singh 2012; Singh et al. 2016).

When attempting to conserve waterlogged archaeological wood, it is essential to consider the drying processes. It is well known that wood cell wall porosity, even in fresh timber, may be altered by drying processes, whereby the changes can be reversible or permanent. The phenomenon of hornification shows that drying of cellulose fibres causes irreversible contraction of the cell wall. As water exits micropores in the cell wall, their walls collapse and shrink, leading to their closure due to the formation of incremental hydrogen bonding. Re-wetting, due to a breakage of some of the hydrogen bonds, can only partially reopen the collapsed micropores. It leads to swelling of the fibres, but the extent of this swelling is much lower than before drying (Luo and Zhu 2011; Park et al. 2006). On the other hand, capillary tension forces during drying induce internal stresses in the cell wall causing its shrinkage. The shrinkage in sound wood is a natural phenomenon, which may be reversible dependent on the drying history of the material. If the shrinkage is reversible, then there will be some hysteresis and relatively minor permanent alteration after re-wetting as the cells return to their previous state (Skaar 1984). However, under stricter drying conditions (like oven-drying), the capillary forces with the high surface tension of evaporating water are strong enough to pull the pore walls together causing reduction in the pore dimensions or even cause their permanent collapse (Hill and Papadopoulos 2001; Park et al. 2006; Stone and Scallan 1965). The drying damage may also result in uneven microcracks within the cell wall (Borrega and Kärenlampi 2011). When conserving freshly excavated decayed waterlogged wood, the problem of damage during drying is greatly amplified due to the degree of wood degradation and the amount of water in the remaining wooden tissue. Deprived of the strengthening cellulose, the remnants of the cell walls in the form of the lignin-rich skeleton of the middle lamellae are strong enough to allow the wood to keep its integrity, while it is saturated with water. However, they do not provide enough strength to resist the surface tension forces of the evaporating water, which can result in a collapse of the whole remaining cell wall. If unprotected, waterlogged wood exposed to air irreversibly shrinks and distorts, losing its form, integrity and original appearance, which is a tremendous loss when it concerns artefacts of cultural heritage (Björdal 2012; Blanchette 2010). Therefore, appropriate conservation and drying techniques need to be applied immediately to preserve wooden artefacts in their unchanged form. The most common technique for waterlogged wood conservation has been consolidation using polyethylene glycol (PEG) treatment in combination with freeze- or slow air-drying (Bjurhager et al. 2010; Cook and Grattan 1990; Grattan 1982; Hoffmann 1986). 
In addition to the above very practical considerations, the changes in the cell wall porosity due to microbial degradation (physical change of the cell wall and cell wall micropore geometry) and drying (additional physical changes in the cell wall and degraded cell wall due to strain, cracking or creation of new pores) have a direct influence on wood-water relationships. As a lignocellulosic material, wood is hygroscopic by its nature. The newly exposed surfaces in the degraded wood are also hygroscopic, but may manifest this effect in a different manner to the classical model of the intact wood cell wall. Management of the hygroscopicity of the archaeological wood is a fundamental concern for the conservator, leading to the consideration of chemical treatments, as discussed later.

The hygroscopic properties of wood stem from the presence of numerous hydroxyl groups of the cell wall polymers which are the main components attracting water. The accessible hydroxyl groups that are able to form hydrogen bonds with water molecules are named sorption sites. Of the main wood components, hemicelluloses have the highest number of sorption sites, compared with cellulose and lignin (Hofstetter et al. 2006; Hill et al. 2010; Engelund et al. 2013). However, the only $\mathrm{OH}$ groups accessible to water molecules are those that are not involved in inter- and intramolecular interactions between wood polymers constituting the cell wall, although there is a phenomenon of progressive release of intermolecular hydrogen bonds which occurs on exposure to water. In addition, the mechanical properties of the cell wall can also affect sorption behaviour. The less energy it takes to swell the cell wall, the higher the moisture content at a given relative humidity will be (Hill et al. 2012a, b). Therefore, it is not only the chemical composition of wood that influences its sorption behaviour but also the microstructure and rheological properties of the cell wall resulting from the characteristics of its particular components, which in the case of archaeological wood, is usually significantly altered by the decay processes (Papadopoulos et al. 2003; Popescu and Hill 2013; Zelinka et al. 2016).

The moisture content influences the weight and density of wood. It also affects its mechanical properties as well as many other characteristics, including thermal and electrical properties. Moreover, appropriate moisture conditions favour the development of wood-decaying fungi and moulds causing loss of wood mechanical strength and aesthetics. Moisture also accelerates wood weathering when exposed outdoors. Strong fluctuations in moisture content lead to wood dimensional changes causing shrinkage or swelling when wood loses or adsorbs moisture, which may result in cracking and irreversible deformations of wood (Kollmann and Cote 1968; Xie et al. 2011b; Rowell 2012). All the above-mentioned factors affect the behaviour of the wood in service, so, knowledge of wood-water relations is of great importance. However, these issues are also crucial for conservators and others who deal with wooden cultural heritage objects. In the case of historic wood (especially waterlogged), the aforementioned phenomena concerning moisture content and its influence on wood properties are magnified, particularly in the case of shrinkage. This is due to a commonly high degree of wood degradation but can also be altered due to the use of conservation agents (particularly PEG), which, although they stabilise wood dimensions, also increase its hygroscopicity leading to degradation or distortion of valuable artefacts 
(Schniewind 1990; Ljungdahl and Berglund 2007; Mortensen et al. 2007; Esteban et al. 2009, 2010; Vorobyev et al. 2017; Guo et al. 2018). The reduction in wood moisture sorption is thus essential for both industry and heritage conservation.

There are several strategies to reduce wood hygroscopicity (Skaar 1988; Hill 2006; Altgen et al. 2018). One of them is chemical modification. Molecules of the applied chemical partially block the potential sorption sites in the cell wall through covalent bonding with the hydroxyl groups of wood polymers. In addition, they can fill the nanopores in the cell wall (bulking), thus reducing the space for moisture (Donath et al. 2004; Hill 2006, 2008; Xie et al. 2011b). As a result, the cell walls become less sensitive to moisture and more dimensionally stable.

One family of chemicals that has been used for wood modification are organosilicon compounds. They have been applied mainly as binding agents, surface modifiers or additives for wood preservatives, increasing wood hydrophobicity, decreasing its biodegradability and flammability or reducing leachability of different chemicals (Donath et al. 2004, 2006a, b; Hill et al. 2004; Kartal et al. 2009; Panov and Terziev 2009; Giudice and Canosa 2017; De Vetter et al. 2010). Owing to the fact that organosilicons can penetrate and bulk the cell wall, they also improve wood dimensional stability (Donath et al. 2004; Mai and Militz 2004; Xie et al. 2011a). Therefore, this group of chemicals has been chosen as potential stabilisers for waterlogged wood. The results of a previous study showed that some of the silanes can genuinely stabilise dimensions of archaeological waterlogged wooden objects upon drying (Broda et al. 2018, 2019a, b). Among them, methyltrimethoxysilane (MTMS) proved to be particularly effective for wood differing in the degree of degradation (Broda and Mazela 2017; Broda et al. 2019b). The mechanism of stabilisation and the influence of the silane on the wood cell wall in the meaning of its porosity and moisture properties, which are important from the conservation point of view, have not been studied yet. It should be noted here, that MTMS, although effective in waterlogged wood stabilisation, has some disadvantages. First of all, it is hazardous for human health and relevant precautions must be taken during its application (Broda et al. 2019b). Moreover, this type of treatment, due to the chemical reactivity of the silane with wood, seems irreversible, which is against one of the key principles in wood conservation. Nevertheless, due to the fact that silane lodges itself in the cell wall and not in the cell lumina, a re-conservation of the silane-treated wood with different chemicals remains possible.

The aim of the presented study was to investigate the influence of methyltrimethoxysilane on the cell wall of waterlogged archaeological wood. A dynamic vapour sorption (DVS) analysis was carried out to analyse water vapour sorption behaviour of archaeological wood and investigate the effect of the silane treatment on its moisture properties. This method has been commonly used to determine sorption behaviour of natural fibres, including wood (Hill et al. 2009; Alix et al. 2009; Hill et al. 2010; Jalaludin et al. 2010; Xie et al. 2011b; Popescu et al. 2014; Ormondroyd et al. 2017a, b). To characterise the cell wall microstructure, surface area and porosity measurements of untreated and treated wood were taken as these properties may help to elucidate both changes in water sorption and the mechanism of stabilisation. 

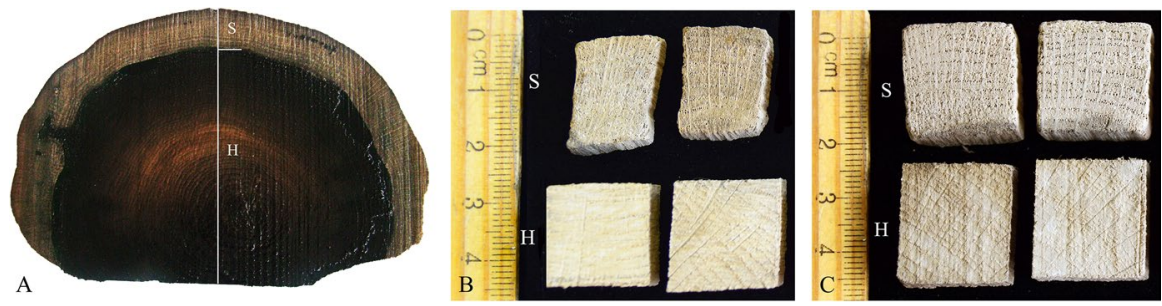

Fig. 1 Cross section of the archaeological waterlogged oak log with two clearly visible wood layers: sapwood (S) and heartwood $(\mathrm{H})(\mathbf{a})$, exemplary air-dried untreated (b) and MTMS-treated (c) waterlogged samples

\section{Materials and methods}

\section{Materials}

The research material was archaeological waterlogged oak (Quercus robur L.) collected from the remains of the medieval "Poznań" bridge buried in the bottom sediments of the Lednica Lake (Poland) (Broda and Frankowski 2017; Broda et al. 2019b). The approximately thousand-year-old log seemed well-preserved and still contained residual sapwood, with the characteristic ring porous structure of oak clearly discernible in the cross section. Two wood layers were distinguished in the log: the outermost sapwood (S) layer and the inner heartwood (H) (Fig. 1a). Spongy to the touch, the light beige sapwood part was severely degraded, soft and fragile. The less decayed heartwood layer was dense and hard, showing a colour gradient ranging from brown to black (Broda et al. 2019b). The diverse extent of wood deterioration made the waterlogged oak a suitable object, on which to conduct research into new conservation treatments. Sound recent oak heartwood of the same species was used as a control.

\section{Methods}

\section{Sample preparation}

In order to study the water vapour sorption of dried archaeological waterlogged wood, small rectangular samples $(20 \mathrm{~mm} \times 20 \mathrm{~mm} \times 10 \mathrm{~mm}$ in the radial $(\mathrm{R})$, tangential (T), and longitudinal (L) directions) were cut out from the heartwood and sapwood layers of the oak log. The samples were dehydrated with $96 \%$ ethanol for 4 weeks, and then, some of them were treated with a solution of 50\% MTMS (XIAMETER ${ }^{\circledR}$ OFS-6070 SILANE, Dow Corning Europe S.A., Belgium) in 96\% ethanol (v/v) using the oscillating pressure method. This consisted of six cycles of vacuum $(0.9$ bar for $0.5 \mathrm{~h})$, pressure $(10$ bars for $6 \mathrm{~h}$ ) and atmospheric pressure (16 h) (Broda et al. 2019b). Treated and untreated samples were removed from the silane solution and ethanol, respectively, and air-dried at room temperature (about $23-25{ }^{\circ} \mathrm{C}$ ) for 2 weeks. Air-drying was used as the simplest representative 
drying method from a conservation perspective. Six replicates of each type of the specimens (Fig. 1b, c) were then ground together and sieved. The fine fraction, with the particle size less than $0.5 \mathrm{~mm}$, was used for the DVS measurements.

\section{DVS measurements}

Sorption analyses were performed using a dynamic vapour sorption (DVS) system (Surface Measurement Systems, London, UK) which allows for accurate measurements of the change in mass of a sample as it adsorbs precisely monitored water vapour concentrations within nitrogen carrier gas. A small amount of wood powder (about $10 \mathrm{mg}$ ) was put into a clean sample holder, which was then carefully attached to a microbalance. The water container in the DVS device was filled with deionised water. Then, the sample chamber was closed and sealed. The flow rate of nitrogen passing over the sample was adjusted to $200 \mathrm{~cm}^{3} \mathrm{~min}^{-1}$. The measurements were taken at a constant temperature of $21{ }^{\circ} \mathrm{C} \pm 0.2{ }^{\circ} \mathrm{C}$. The schedule for the DVS was set to start at $0 \%$ RH and then increase in 5\% steps up to $95 \%$ for the adsorption phase and the reverse for the desorption phase. The instrument maintained the sample at a constant RH until the equilibrium was reached, i.e. the ratio of change in mass in relation to change in time was less than $0.002 \%$ per minute for at least $10 \mathrm{~min}$. These settings give a good compromise between the practicality of measurements and accuracy, although if the time for each humidity stage was greatly extended, then slightly higher EMC values may have resulted (Glass et al. 2017). The running time, target and actual RH, and mass change data were recorded every $20 \mathrm{~s}$ throughout the isotherm run. As the actual conditions inside the chamber may have been slightly different to the pre-set conditions, the integral humidity and temperature probes located close to the sample monitored the actual values, and these data were used in the analysis of the isotherms. When considering modified wood, the amount of the chemical agent within the wood structure should be taken into account. In the analysis of the data, the weight per cent gain (WPG) of the treated samples was used to calculate the mass of the silane within the sample. The actual mass of wood within the silane-modified sample was then calculated. Mass changes due to moisture absorption were then calculated based on the wood mass within the sample.

\section{Scanning electron microscopy}

Micro- and nanostructure of hydrated waterlogged oak was analysed on a Carl Zeiss AG-EVO ${ }^{\circledR} 50$ scanning electron microscope using a cryo-SEM technique. The structure of air-dried archaeological wood was analysed using a Hitachi SU3500 scanning electron microscope equipped with the BSE-3D detector. Specimens were cut into smaller pieces using a razor blade and coated with a thin layer of gold. Then, the samples were mounted in the specimen holder and analysed. Silane-modified archaeological wood was also prepared by this method for observation. 


\section{Surface area and porosity measurements}

The surface area and porosity of the cell wall of treated and untreated waterlogged wood were characterised using a Gemini surface area analyser (Micromeritics Instrument Corporation, Georgia, USA) and a nitrogen absorption method. It should be noted that this method does not allow for evaluation of the total porosity of the material as its determination range of pore diameter is only about 4-300 nm (Hill and Papadopoulos 2001; Kang et al. 2018; Plötze and Niemz 2011; Westermarck 2000). This is narrower than that of some other methods, for example, mercury intrusion porosimetry (pore diameter of about $3 \mathrm{~nm}-200 \mu \mathrm{m}$ ) that are also used for wood characterisation. Nevertheless, nitrogen absorption is a very useful and accurate tool to make comparisons between the microstructure (in the meaning of microvoids) of degraded cell walls.

The samples were cut into smaller pieces (about $5 \mathrm{~mm} \times 5 \mathrm{~mm} \times 10 \mathrm{~mm}$ ), de-gassed and oven-dried at $50{ }^{\circ} \mathrm{C}$ for $24 \mathrm{~h}$. Then, they were placed into glass tubes connected to the Gemini analyser and measured. Since it was observed that the typical sample preparation procedure that involves oven-drying and de-gassing causes significant further shrinkage of the analysed wood, air-dried samples without any additional operation were also used for the measurements (similarly for recent wood). The obtained values represent the characteristics of the cell wall of naturally air-dried waterlogged wood. However, the aim of the study also was to investigate the influence of the silane treatment on the cell wall structure since silane stabilises wood dimensions preventing its shrinkage. Therefore, the intact microstructure of waterlogged unshrunken wood was also required to make comparison with the treated wood. To achieve this, waterlogged samples were $\mathrm{CO}_{2}$ critical point dried (with the use of a E3000 Series Critical Point Dryer (Quorum Technologies LTD, UK)) as this is the best method to minimise wood shrinkage (measurement of wet wood is impossible using the gas sorption method). The $\mathrm{N}_{2}$ adsorption-desorption isotherms were recorded at liquid nitrogen temperature. The surface area was calculated using Micromeritics Stardriver software according to the Brunauer-Emmet-Teller (BET) theory (Brunauer et al. 1938), based on the volume of nitrogen absorbed at different partial pressures. The Barrett-Joyner-Halenda (BJH) method was used to characterise wood porosity (Barrett et al. 1951).

The volumetric shrinkage of samples dried under various conditions was calculated on the basis of their dimensions before and after drying. The dimensions of each sample were measured in all three anatomical directions (five measurements along each edge) using a digital calliper $( \pm 0.01 \mathrm{~mm})$, and the mean values were used to calculate volumetric shrinkage. The applied method, although not very precise, was sufficient to make comparisons between different treatment and drying methods.

\section{Results and discussion}

\section{The cell wall characteristics}

The results of surface area, total pore volume and shrinkage of recent and archaeological oak wood dried under different conditions are presented in Table 1. It is 
Table 1 Mean values of surface area (5 measurements of each wood type), total pore volume and volumetric shrinkage (Sh) of sound recent oak (CO) and waterlogged archaeological oak sapwood (S) and heartwood (H), unmodified and modified with MTMS, oven-dried (od), air-dried (ad) and dried at critical point (cp), respectively (* results of the previous research Broda et al. 2019b)

\begin{tabular}{llcll}
\hline Wood type & Treatment, drying & Surface area $\left(\mathrm{m}^{2} \mathrm{~g}^{-1}\right)$ & $\begin{array}{l}\text { Total pore volume } \\
\left(\mathrm{cm}^{3} \mathrm{~g}^{-1}\right)\end{array}$ & Sh $(\%)$ \\
\hline $\mathrm{S}$ & No, od & $2.89 \pm 0.13$ & 0.0062 & $40.3 \pm 4.6$ \\
$\mathrm{~S}$ & No, ad & $4.14 \pm 0.16$ & 0.0146 & $39.9 \pm 2.9^{*}$ \\
$\mathrm{~S}$ & No, cp & $34.74 \pm 0.98$ & 0.0890 & $4.2 \pm 1.1$ \\
$\mathrm{~S}$ & MTMS, ad & $1.09 \pm 0.05$ & 0.0020 & $-1.4 \pm 0.6^{*}$ \\
$\mathrm{H}$ & No, od & $0.57 \pm 0.01$ & 0.0019 & $16.7 \pm 0.5$ \\
$\mathrm{H}$ & No, ad & $0.64 \pm 0.01$ & 0.0018 & $16.3 \pm 1.7^{*}$ \\
$\mathrm{H}$ & No, cp & $2.78 \pm 0.28$ & 0.0058 & $7.1 \pm 0.7$ \\
$\mathrm{H}$ & MTMS, ad & $0.30 \pm 0.05$ & 0.0014 & $6.1 \pm 0.5^{*}$ \\
$\mathrm{CO}$ & No, ad & $0.47 \pm 0.03$ & 0.0011 & - \\
\hline
\end{tabular}

evident that drying conditions correspond to wood shrinkage and thus, its porosity, regardless of the degree of wood degradation. The smallest surface area (SA) and the lowest total pore volume (TPV) were obtained with the most shrunken oven-dried wood, while less distorted samples dried at critical point had the highest SA and TPV values. A similar relationship between the different drying methods (resulting in shrinkage level due to collapse of micropores) and the surface area was observed, i.e. for eucalyptus wood flour by Kang et al. (2018), for pine wood flour and holocellulose by Papadopoulos et al. (2003), wood pulp by Weatherwax and Caulfield (1971) or spruce wood by Stone and Scallan (1965). The relationship between the degree of degradation and wood porosity is also visible, irrespective of the drying method. The lowest SA and TPV were obtained with air-dried sound recent oak. For comparison, with less dense oven-dried spruce wood, surface areas ranging between 0.6 and $0.8 \mathrm{~m}^{2} \mathrm{~g}^{-1}$ were determined using the same measurement technique (Hill and Papadopoulos 2001). For degraded wood, irrespective of the drying method, the values were only slightly higher for slightly degraded heartwood and significantly higher for severely decayed sapwood. The results are in line with the chemical and physical characteristics of the same archaeological oak that has previously been published (Broda et al. 2019b). It is important to stress that the results for oven-dried or air-dried waterlogged wood do not represent the real porosity of waterlogged wood due to its shrinkage. Only the data obtained with wood dried at the critical point can be considered as closest to the original waterlogged wood fully saturated with water.

More detailed characteristics of pore size and distribution in waterlogged archaeological wood are presented in Fig. 2. Generally, three pore size classes are distinguished: micropores $(<2 \mathrm{~nm})$, mesopores $(2-50 \mathrm{~nm})$ and macropores $(>50 \mathrm{~nm})$ (Ormondroyd et al. 2017b). However, it should be mentioned that the nitrogen absorption method does not give reliable results for pores with the diameter below $4 \mathrm{~nm}$. Generally, in the method used, emptying of the pores depends on the diameter of the meniscus of the liquid nitrogen at the filled pore throat. The larger the 

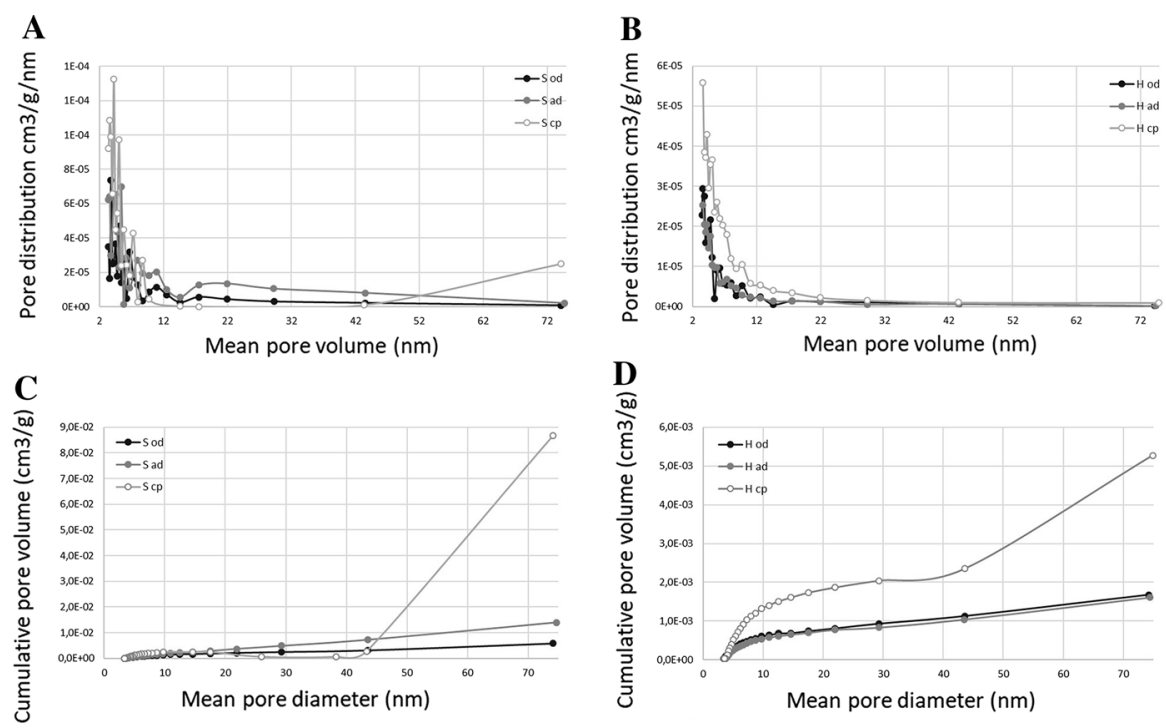

Fig. 2 Pore distribution as a function of the pore volume $(\mathbf{a}, \mathbf{b})$ and cumulative pore volume as a function of the pore radius $(\mathbf{c}, \mathbf{d})$ illustrating the different distribution types of waterlogged archaeological oak sapwood $(\mathrm{S})$ and heartwood $(\mathrm{H})$ depending on the drying method: $o d$ oven-dried at $50{ }^{\circ} \mathrm{C}$, ad air-dried, $c p$ dried at critical point

diameter, the higher the pressure at which the pore will empty, which is determined using the Kelvin equation. In the case of a pore diameter less than $4 \mathrm{~nm}$, nitrogen does not behave as a classical liquid and all the pores tend to empty spontaneously at the pressure $P / P_{o}=0.4$. In this case, the Kelvin equation is not valid anymore. Nevertheless, the method can still be used for making a comparison between the tested wood samples.

According to the above-mentioned classification, it is clear that in the tested wood, regardless of the drying method, the prevailing fractions are micropores and small mesopores typical for wood (Fig. 2a, b). However, in the case of sapwood, the presence of larger macropores is also visible, and a distinction in the pore distribution pattern and the cumulative pore volume between sapwood and heartwood can be noticed. This is the result of the different degree of degradation of the particular wood layers mentioned above. As shown in Fig. 3, cryo-SEM micrographs give an insight into the microstructure of hydrated waterlogged oak wood. From Fig. 3a, b, a significant difference in the decay extent between sapwood and heartwood is evident. The sapwood cell walls are very thin (Fig. 3a, c, e) and consist mainly of middle lamellae (that indicates an advanced decay by soft-rot and/or erosion bacteria) which are riddled with smaller and larger holes (with a diameter of about $2 \mu \mathrm{m}$ and smaller) which will increase their porosity (Fig. 3e). Apart from that, the cell lumina are filled with insubstantial, unstructured networks of heavily degraded S2 debris, which may affect the surface area and porosity and also explain the presence of larger pores in the highly degraded sapwood structure. In comparison, the cell walls of heartwood are still thick 

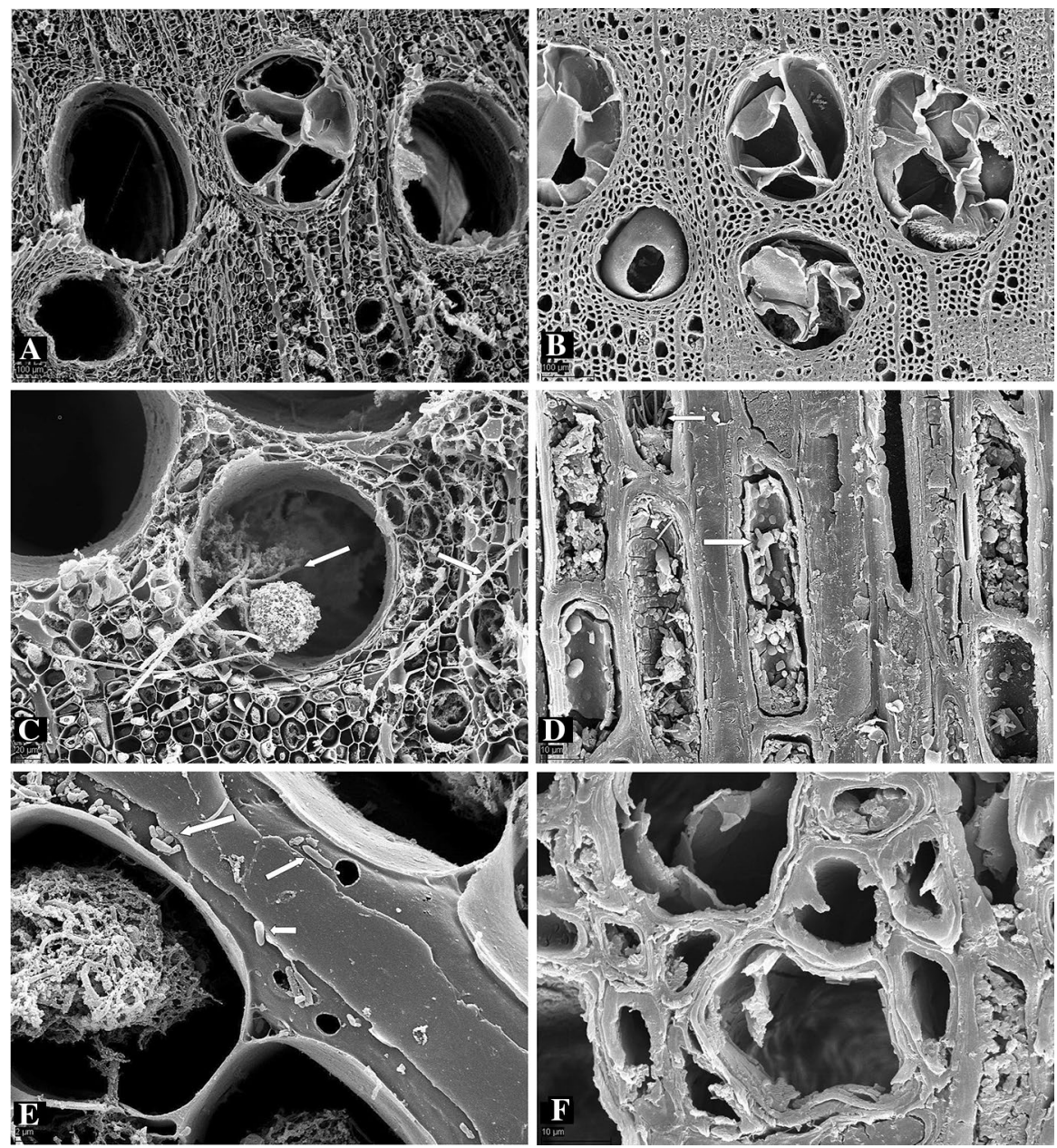

Fig. 3 Cryo-SEM micrographs of waterlogged oak: a, c, e cross sections of oak sapwood showing typical soft-rot and erosion bacteria decay with only the middle lamellae skeleton remained in advanced stages of microbial attack and the cell lumina filled with slime and breakdown products; $\mathbf{c}$ in some cells the S3 layer is still visible, which is characteristic for soft-rot decay, arrows indicate fungal hyphae; e smaller and larger holes in the middle lamella are visible (with diameter of about $2 \mu \mathrm{m}$ and much smaller) that suggest tunnelling bacteria decay, arrows indicate bacterial cells; $\mathbf{b}, \mathbf{f}$ cross sections and d longitudinal section of oak heartwood showing moderate decay, with the cell walls still consisted of all the layers, however with visible signs of decay in the form of multiple cavities and zones of erosion (soft-rot and erosion bacteria) (d, f) within S2 and detaching of particular cell wall layers; $\mathbf{d}$ arrows indicate fungal hyphae and bacteria in the cell lumina filled with breakdown products (Björdal et al. 1999; Daniel 2014; Hoffmann and Jones 1990)

and composed of all the layers (Fig. 3b, d, f). However, signs of moderate decay are clearly visible in the form of numerous cavities, crevasses and detachments within the heartwood cell walls, which explains the pattern of pore distribution shown in Fig. 2. 

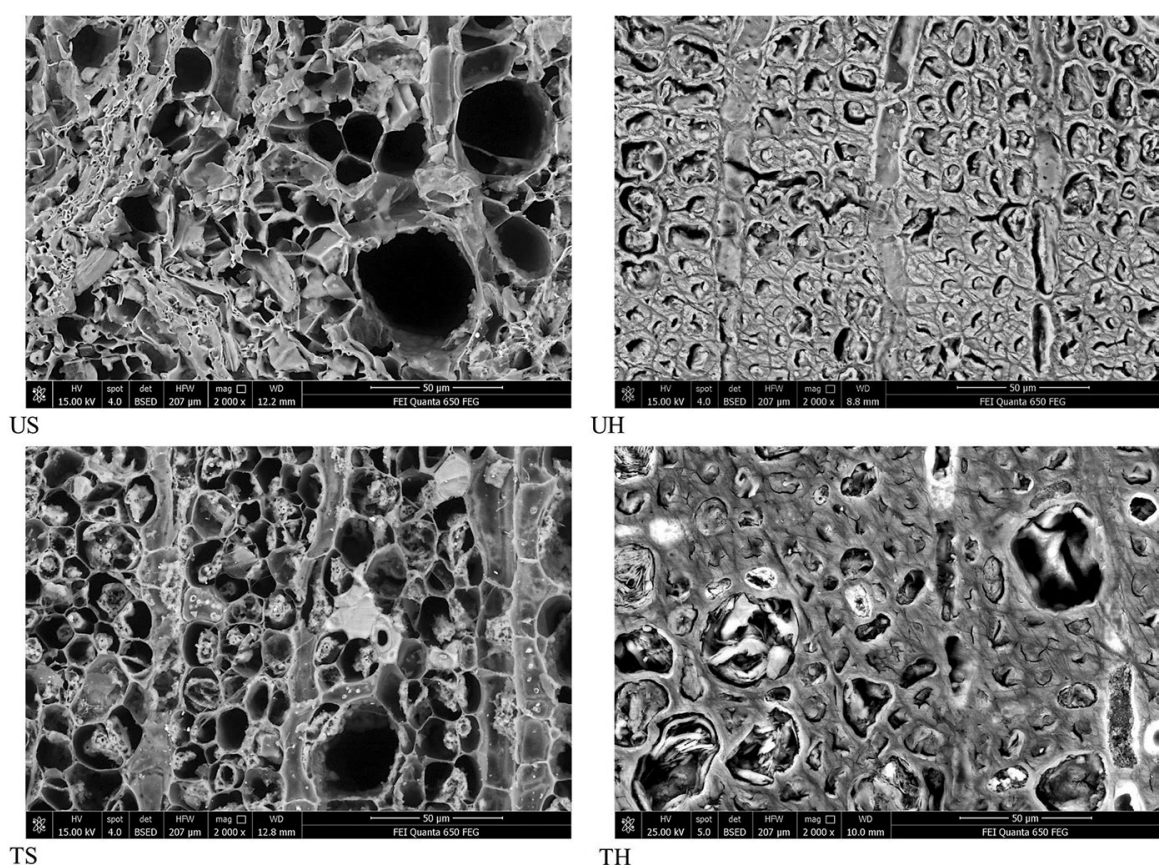

$\mathrm{UH}$

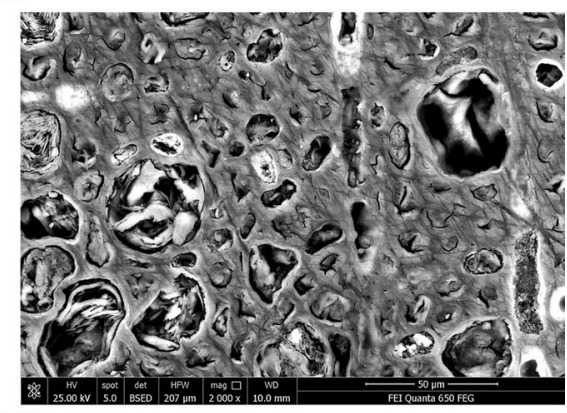

TH

Fig. 4 SEM images of air-dried untreated (first row, U) and MTMS-treated (second row, T) waterlogged oak specimens ( $S$ sapwood, $H$ heartwood)

It is noticeable that the cumulative pore volume decreases with the shrinkage due to the stringent drying conditions (Fig. 2, Table 1), which is characteristic for lignocellulosic materials in general (Kang et al. 2018; Papadopoulos et al. 2003; Park et al. 2006; Stone and Scallan 1965). However, the different pattern of changes in cell wall pore size distribution between highly degraded sapwood and moderately decayed heartwood dried under various conditions can be observed. In heartwood, the volume of micro- and mesopores is just diminishing as the wood shrinkage increases. In sapwood, the reduction of the cell wall micro- and smallest micropores $(<10 \mathrm{~nm})$ is also evident but, due to the collapse of the biggest macropores upon airor oven-drying, a new fraction of mesopores appears and the amount of macropores significantly decreases (Fig. 2a, c). Considering the fact that the S2 layer debris are visible in cp- (Fig. 3c, e) and not in air-dried sapwood (US in Fig. 4) along with the patterns of pore distribution in cp- and air-dried samples, it could be suggested that these structures are related to the presence of macropores in highly decayed waterlogged sapwood. 
By comparing the patterns of pore distribution and cumulative pore volume of recent and waterlogged wood (Figs. 5a and 6a), the difference resulting from wood degradation is clearly visible. With sound recent oak, the quantity of pores (mainly micro- and small mesopores) and cumulative pore volume in the cell walls is noticeably lower than with lightly degraded heartwood and significantly reduced in comparison with severely decayed sapwood, which is furthermore characterised by the presence of macropores.

As reported before, MTMS treatment of archaeological waterlogged oak resulted in its dimensional stabilisation (Broda et al. 2019b). This effect was particularly notable in the case of archaeological oak sapwood, where MTMS limited wood shrinkage almost completely (from $28 \%$ shrinkage seen for untreated wood) (Table 2). The stabilising effect is clearly visible in the macroscopic picture of sapwood samples (Fig. 1c), as well as in the SEM micrograph (Fig. 4, sample TS), where the cell walls are not collapsed and the cells retained their regular shape. In the case of waterlogged oak heartwood, shrinkage was reduced from about $7 \%$ (untreated wood) to about 3\%. The difference between the silane anti-shrink efficiency for sapwood and heartwood resulted from its WPG (Table 2) that was dependent on the degree of wood degradation (thus wood density) (Broda et al. 2019b). The chemical modification by silane was also reflected in significant changes in the cell wall porosity when comparing the results of treated samples with untreated wood dried at critical point, as only this result represents real porosity of waterlogged wood (Table 1). In the case of heartwood, the surface area decreased more than nine times and the pore volume decreased about four times. For sapwood samples, SA decreased even more, nearly 32 times and TPV decreased by 44 times. The pore size and distribution patterns of treated and untreated heartwood are similar (Fig. 5b); however, the decrease in pore volume after treatment is discernible (Figs. 5b, 6b). In the case of sapwood, the difference is even more pronounced (Figs. 5c, 6b) as the silane treatment resulted in the significant reduction in the total volume of pores of all sizes making the pattern of pore size and distribution similar to that of the recent oak or treated waterlogged heartwood.

The observed reduction in surface area and total pore volume of treated waterlogged wood can be explained by a mechanism of wood modification by the silane. It has been shown that small MTMS molecules can penetrate and encrust the cell wall pores creating a uniform coating on the cell wall surface (Donath et al. 2004; Mai and Militz 2004). In the case of degraded wood, the encrustation seems particularly effective as the pores in its cell walls are larger. The results obtained indicate the veracity of this mechanism as reinforcement of the cell wall was observed indicated by the dimensional stabilisation and reduction of the surface area and total pore volume of the treated archaeological wood. It should be noted, however, that the effect of chemical modification on the cell wall was clearly visible despite the differences in shrinkage between untreated wood dried under various conditions (Table 1). Untreated wood shrank significantly upon oven- or air-drying (especially sapwood) due to the cell wall collapse caused by the internal forces of hydrogen bonding between polysaccharide components, which disrupted its porous nature thus reducing surface area and total pore volume. Therefore, the values of the measured surface area and the micropore network were smaller than the expected real values 
Fig. 5 Pore distribution as a function of the pore volume illustrating the different distribution types of recent and waterlogged archaeological oak sapwood $(\mathrm{S})$ and heartwood $(\mathrm{H})(\mathbf{a})$, untreated dried at critical point (U) and MTMS-treated air-dried (T) waterlogged sapwood (b) and untreated and MTMS-treated waterlogged heartwood (c)

for waterlogged wood (drying at critical point allowed to maintain wood structure almost unchanged, and the porosity values obtained for these samples can be considered as real porosity of hydrated waterlogged wood). In the case of treated wood, the shrinkage was reduced and the spatial structure of the cell wall remained "developed" (similar to the original structure of fully waterlogged wood). Theoretically, when considering only the cell wall collapse and wood shrinkage without the coating effect of the silane, we would expect that the porosity of the treated and almost unshrunken samples should be similar to untreated wood dried at the critical point and higher than for untreated and shrunken air- or oven-dried ones. The observed opposite effect of porosity reduction in the treated wood clearly indicates that the silane was embedded in the pores and thus reduced the porosity and preserved the spatial structure of the cell wall.

\section{DVS measurements}

Figure 7 presents the sorption isotherms reported as EMC against RH and the absolute hysteresis for the heartwood and sapwood of the air-dried degraded waterlogged oak wood and for sound recent oak. Although for the detailed moisture sorption characteristics two adsorption/desorption cycles are usually recorded, it was decided to focus on the single cycle, as the aim of this research was to compare the moisture properties of sound and degraded wood treated and untreated with silane. For sound recent oak, the maximum EMC of $21.8 \%$ was at $92.5 \% \mathrm{RH}$. The adsorption and desorption isotherms of archaeological oak sapwood and heartwood almost coincide, with the maximum EMC of about $23 \%$ at around $88 \% \mathrm{RH}$.

The observed increase in moisture sorption of degraded wood is in line with the data published by, for example, Hoffmann (1986), Schniewind (1990), Ljungdahl and Berglund (2007), Esteban et al. (2009, 2010) or Guo et al. (2018). They observed increased hygroscopicity of decayed archaeological wood of different species, even though it might be expected that degradation of the most hydrophilic wood hemicelluloses should reduce hygroscopicity due to preferential removal of the amorphous polysaccharide component, which dominates the hygroscopic behaviour. Hoffmann (1986) explains this phenomenon by an increased porosity of the degraded cell wall resulting in greater capillary condensation (and more pronounced capillary forces for water absorption). This is consistent with the results of the present research as higher porosity of the cell wall of archaeological wood (regardless of the drying method and resulting shrinkage) was observed in comparison with recent wood (discussed above). As wood is a dynamic/swelling material, the observed phenomenon might also be a result of a reduction in mechanical resistance of the degraded cell walls due to the internal swelling pressure exerted by the sorbed water molecules. However, there are a number of alternative hypotheses. 

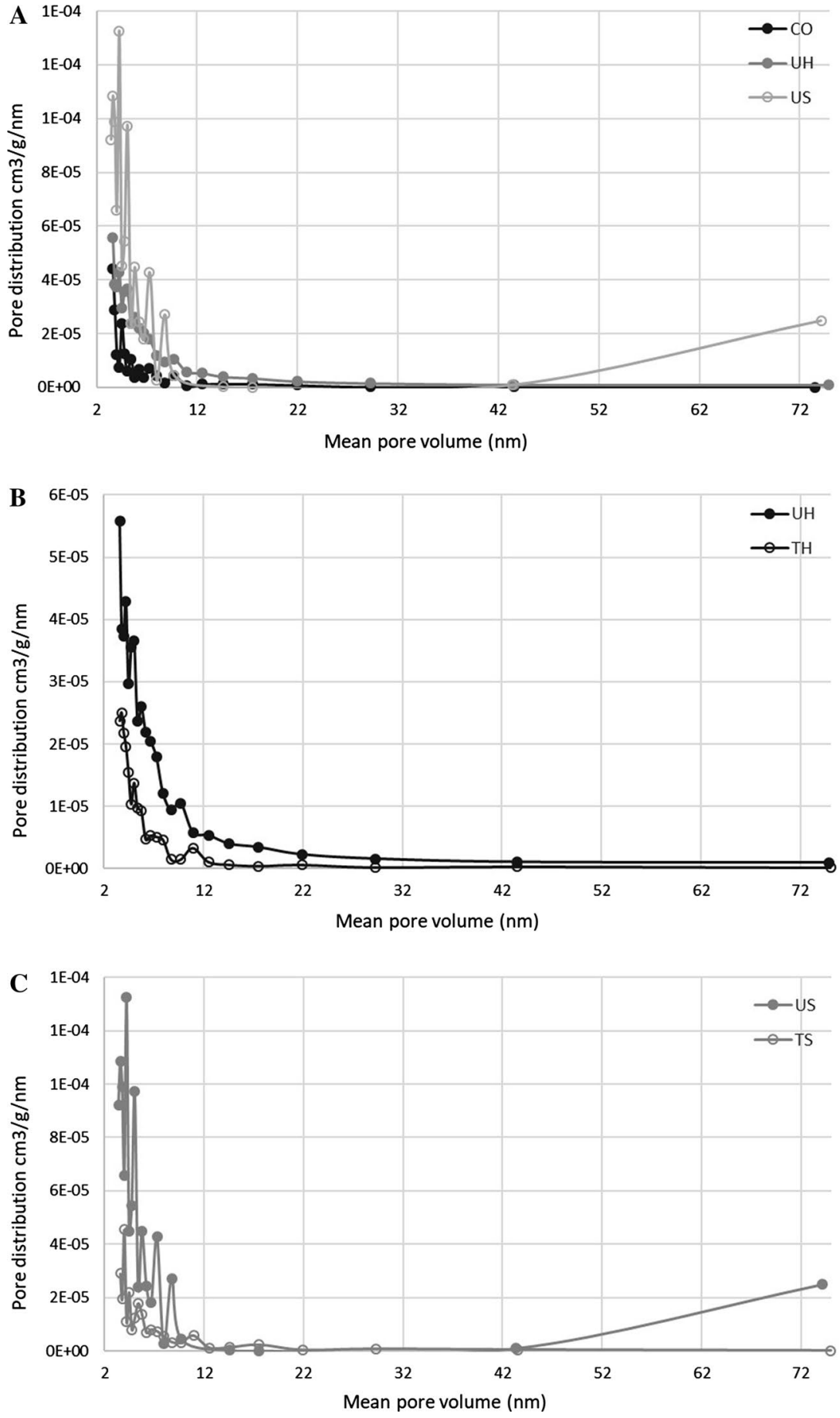

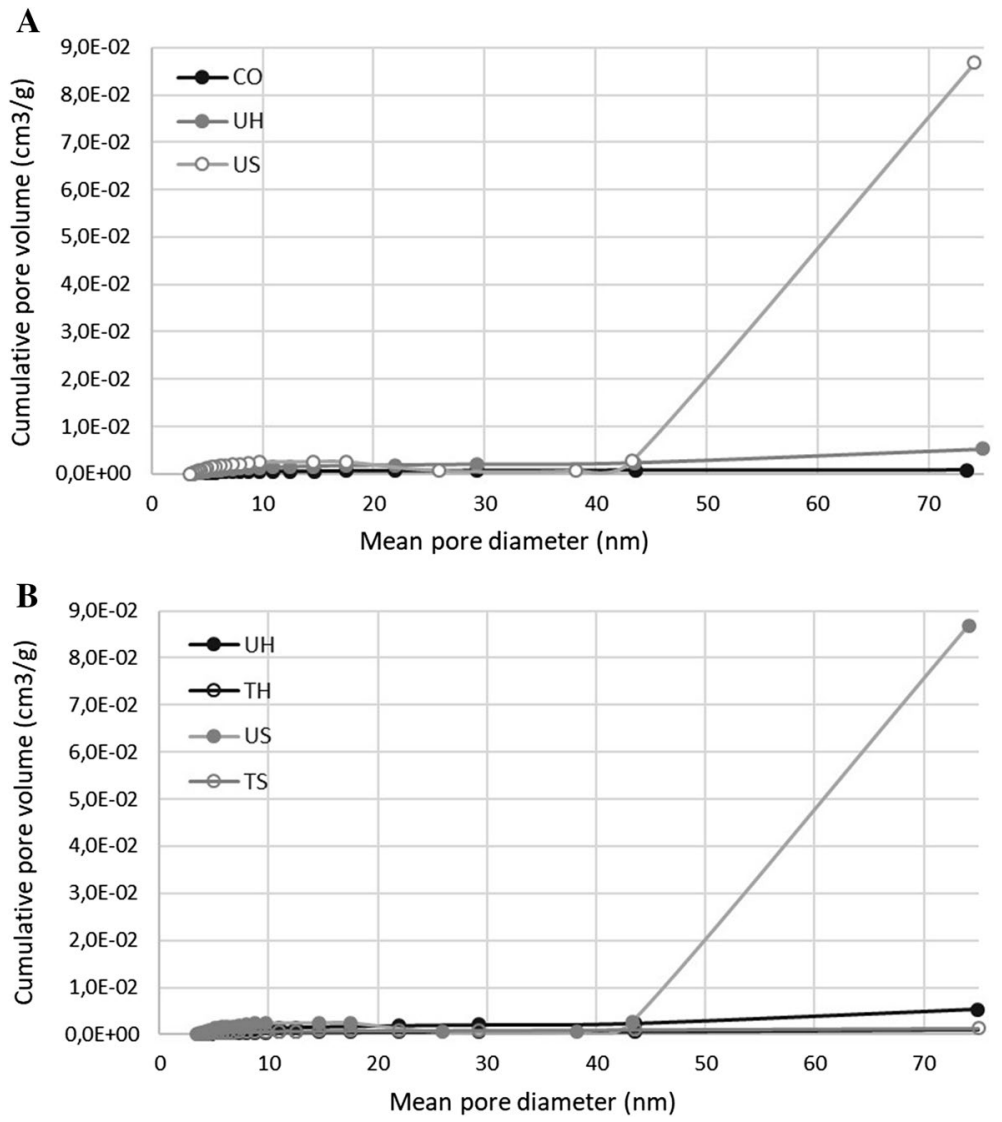

Fig. 6 Cumulative pore volume as a function of the pore radius illustrating the different distribution types of recent and waterlogged archaeological oak sapwood $(\mathrm{S})$ and heartwood $(\mathrm{H})(\mathbf{a})$ and untreated dried at critical point (U) and MTMS-treated air-dried (T) waterlogged sapwood and heartwood (b)

Table 2 WPG, cross-sectional shrinkage (Sh) and cross-sectional anti-shrink efficiency (ASE) of waterlogged oak wood treated with MTMS: $S$ sapwood, $H$ heartwood (Broda et al. 2019b); shrinkage of untreated wood is given in brackets

\begin{tabular}{llll}
\hline Wood layer & WPG $(\%)$ & Sh $(\%)$ & ASE (\%) \\
\hline $\mathrm{S}$ & $111.27 \pm 11.41$ & $0.01(28.09)$ & 99.96 \\
$\mathrm{H}$ & $21.63 \pm 1.19$ & $3.31(7.17)$ & 53.84 \\
\hline
\end{tabular}

For example, Esteban et al. (2009, 2010) and Guo et al. (2018) explain increased hygroscopicity of waterlogged wood by changes within the polysaccharides. They showed that, although the process of decomposition of archaeological wood caused degradation of hemicelluloses, it also decreased the crystallinity index of the cellulose and the length of the crystalline regions, which resulted in the emergence of the new sorption sites. Thus, the equilibrium moisture content and the hysteresis 

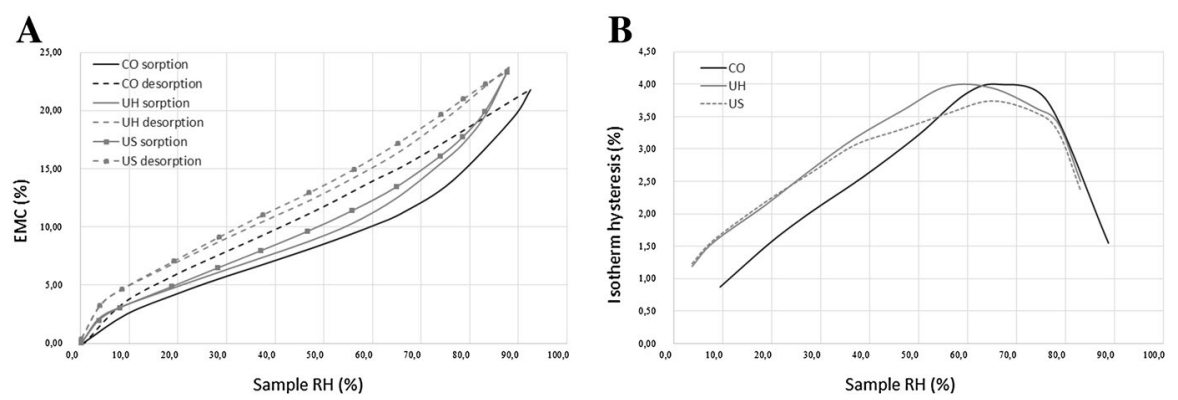

Fig. 7 Water sorption isotherms (a) and hysteresis (b) for recent oak (CO) and untreated air-dried waterlogged oak sapwood (US) and heartwood (UH)

observed were higher than for recent wood. Furthermore, according to Ljungdahl and Berglund (2007), the oxidation of chemical groups in wood polymers during degradation also increases hygroscopicity. This observation agrees with the results of FT-IR and XRD analyses for the same oak wood by Broda and Popescu (2019). It was shown that archaeological oak sapwood was characterised by high degradation of polysaccharides and low crystallinity level, while oak heartwood only displayed slight decay of polysaccharides with a crystallinity similar to recent oak. Additionally, different moisture properties between sound and degraded wood could result from the different content of extractives. Skaar (1984) concluded that hygroscopicity of wood with high extractive content is generally lower than this without extractives and in the case of one-thousand-year old waterlogged oak, a very low extractives concentration could be expected. The sorption isotherm is also dependent on the mechanical properties of the cell wall-the weaker (more degraded) the cell wall is, the more water it absorbs, since the equilibrium is affected by a balance of the swelling pressure of the absorbed water and the ability of the cell wall to resist this pressure. Brown rot fungal decay has been shown to sequentially degrade hemicelluloses during initial stages of decay, leading to considerable strength loss of wood at the macroscale (Curling et al. 2002). It makes logical sense that any degradation of the hemicelluloses would have a similar effect on the strength of the cell wall. In the case of highly degraded wood, it is possible that the hygroscopicity is determined by more than one of these effects.

It is interesting that although the degree of degradation and porosity of archaeological sapwood is higher than of heartwood, their sorption isotherms are similar. The possible reason is that the high shrinkage of the highly degraded sapwood decreased its surface area, thus, decreasing its potential hygroscopicity to the level similar to less degraded heartwood.

The absolute hysteresis of air-dried degraded waterlogged oak wood and sound recent oak presented in Fig. $7 \mathrm{~b}$ is relatively similar, but the peak in the degraded sapwood is offset to a lower moisture content. On looking at the sorption section of the curve (Fig. 7a), UH sorbs more readily on initial increase in relative humidity than US, while desorption occurs at a similar rate throughout. This may indicate that the sapwood sorption sites, which closed due to hydrogen bonding between 
$\mathbf{A}$

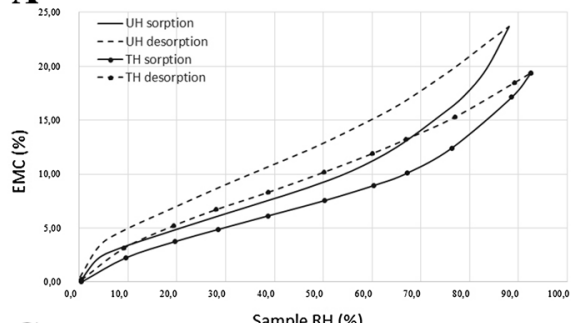

$\mathbf{C}_{2}$

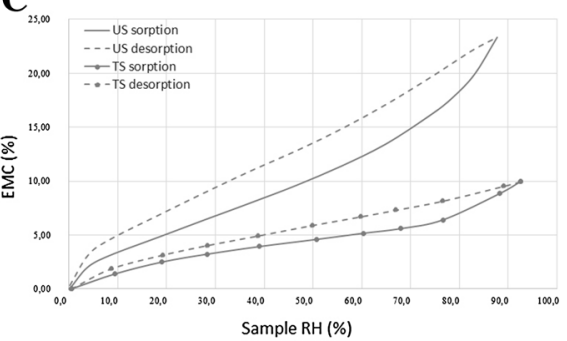

B

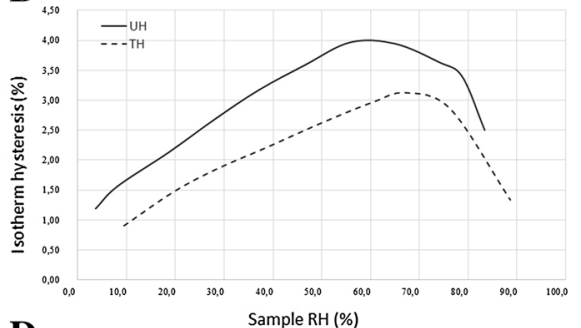

D

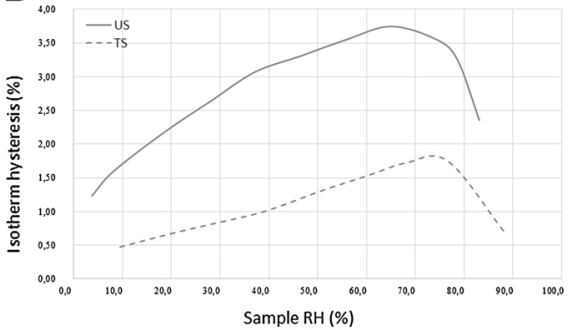

Fig. 8 Water sorption isotherms (a, c) and hysteresis (b, d) for untreated (US) and MTMS-treated waterlogged oak sapwood (TS) and untreated (UH) and MTMS-treated waterlogged oak heartwood (TH) not corrected for the extra weight of the silane inside the wood structure

degraded internal surfaces, are slower to reopen in the presence of moisture vapour than the less degraded heartwood.

It is clear from Fig. 8a, c that MTMS treatment of archaeological oak wood resulted in a notable decrease in hygroscopicity of the newly formed wood/silane entity as a whole, compared to an untreated sample. The maximum EMC for heartwood decreased from $24 \%$ for untreated to $19 \%$ for treated wood. In the case of sapwood, the maximum EMC decreased even more significantly from 23 to $10 \%$. This could be explained by the reduction in the surface area and total pore volume of the treated wood as discussed above (a bulking mechanism that reduces room for water molecules) or a chemical modification of wood by the applied silane that potentially could react with wood hydroxyls reducing the number of sorption sites. However, when considering chemically modified wood it is vital to take into account the presence of the applied chemical agent. Therefore, the isotherms were corrected for the weight of silane inside the wood structure (Fig. 9a, c). These isotherms reflect the moisture properties of the modified wood component itself. From this, it can be seen that for heartwood, the difference in maximum EMC between modified and unmodified samples is not significant. In the case of sapwood, the difference in maximum EMC is slightly greater as it decreased from 24 to $21 \%$. Such small differences between maximum EMC of untreated and treated wood point rather at a bulking mechanism than chemical modification by silane.

The difference in sorption behaviour between treated archaeological sapwood and heartwood could be explained by the amount of silane accumulated in wood during the impregnation process. As WPG of the sapwood was about $111 \%$ in comparison 
A

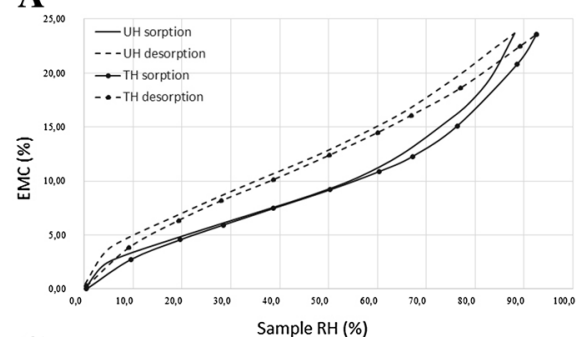

C

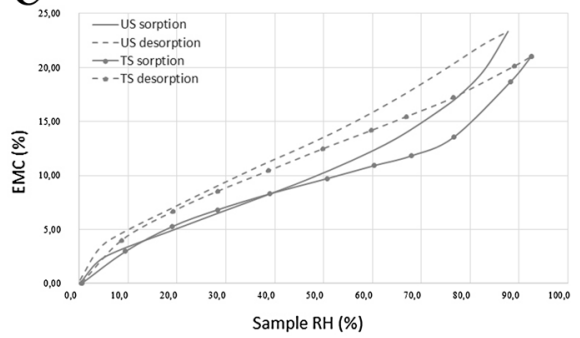

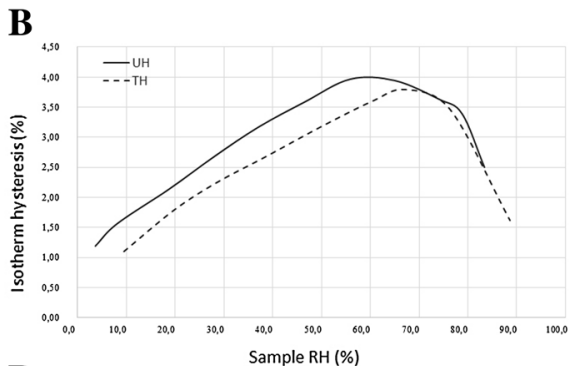

D

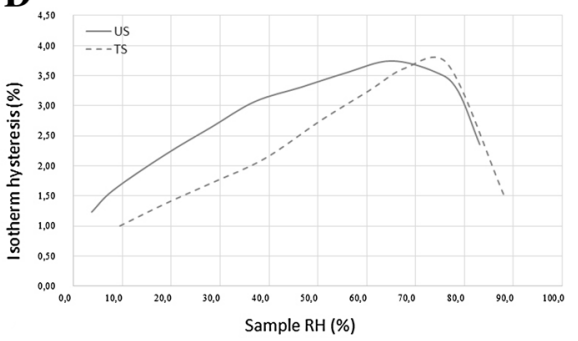

Fig. 9 Water sorption isotherms (a, c) and hysteresis (b, d) for untreated (US) and MTMS-treated waterlogged oak sapwood (TS) and untreated (UH) and MTMS-treated waterlogged oak heartwood (TH) corrected for the extra weight of the silane inside the wood structure

with $21 \%$ for heartwood (Table 2), the lower hygroscopicity of the former is not surprising.

The impregnation also resulted in a reduction in hysteresis between treated and untreated wood (Fig. 8b, d). It was particularly notable for archaeological oak sapwood as a result of higher level of silane absorption in comparison with heartwood. However, looking at the plots when silane content is taken into account (Fig. 9b, d) then it can be seen that the difference in levels of hysteresis is reduced. However, irrespective of whether silane weight is used, a marked shift in the humidity at which the peak hysteresis occurs can be observed with treated wood (Figs. 8b, d and $9 \mathrm{~b}, \mathrm{~d})$. This shift moves the hysteresis plot so that it appears similar to that for the undegraded recent wood, with peak hysteresis seen at approximately $60 \% \mathrm{RH}$ rather than at 70 to $80 \% \mathrm{RH}$ for the untreated wood. It can result from an increased rigidity of the cell wall due to the silane presence (Hill et al. 2012a, b; Keating et al. 2013) as it was shown that silane treatment improves mechanical properties of fibre and wood composites (Bengtsson and Oksman 2006; Bisanda and Ansell 1991; Hafezi et al. 2016).

Previous DVS experiments revealed a chemical instability of the MTMS-waterlogged elm wood system (Broda et al. 2018). During the experiment, the mass of the MTMS-treated sample systematically decreased below the initial dry mass during the desorption stage. This effect was explained by gel ageing and the resulting mass loss of evaporating by-products of the sol-gel process, which takes place upon alkoxysilane polymerisation, and the effect was neutralised only after 12 cyclic sorption stages. The present experiment did not demonstrate such instability of the silane. It can be explained by the lower concentration of MTMS in treated oak in 
comparison with treated elm (WPG of $111 \%$ and $21 \%$ for oak sapwood and heartwood and $242 \%$ for elm) and the resulting full alkoxysilane polymerisation. This observation shows that an additional stage of wood seasoning to stabilise the MTMS inside its structure is required only in the case of particularly high silane absorption (which takes place when wood is highly degraded and permeable), which seems to be important from the wood conservation perspective.

\section{Conclusion}

This study indicated that methyltrimethoxysilane effectively encrusted/covered the cell wall structure of archaeological wood. However, the silane was seen to not only encrust the cell wall but also be embedded in the pores and thus preserved the spatial structure of the cell wall. This resulted in dimensional stabilisation of the treated wood and a decrease in hygroscopicity. DVS experiments revealed significant differences in hysteresis between silane-treated and untreated degraded wood, indicating that the silane modification had inhibited the collapse of micro pores. This confirms that MTMS treatment is an efficient technique for preserving the microstructure of archaeological waterlogged wood that makes it potentially useful in conservation of waterlogged wooden artefacts.

Funding The research was funded by the Polish Ministry of Science and Higher Education as part of the "Cultural heritage - research into innovative solutions and methods for historic wood conservation" project (No. 2bH 150037 83) and by the STSM Grant from COST Action FP1407 [COST STSM reference number: COST-STSM-FP1407-39990]. The authors would like to thank Professor Nina Elisabeth Nagy from the Norwegian Institute of Bioeconomy Research for her help in the cryo-SEM analysis.

\section{Compliance with ethical standards}

Conflict of interest The authors declare that they have no conflict of interest.

Open Access This article is distributed under the terms of the Creative Commons Attribution 4.0 International License (http://creativecommons.org/licenses/by/4.0/), which permits unrestricted use, distribution, and reproduction in any medium, provided you give appropriate credit to the original author(s) and the source, provide a link to the Creative Commons license, and indicate if changes were made.

\section{References}

Alix S, Philippe E, Bessadok A, Lebrun L, Morvan C, Marais S (2009) Effect of chemical treatments on water sorption and mechanical properties of flax fibres. Bioresour Technol 100(20):4742-4749. https://doi.org/10.1016/j.biortech.2009.04.067

Altgen M, Willems W, Hosseinpourpia R, Rautkari L (2018) Hydroxyl accessibility and dimensional changes of Scots pine sapwood affected by alterations in the cell wall ultrastructure during heat-treatment. Polym Degrad Stab 152:244-252. https://doi.org/10.1016/j.polymdegradstab .2018.05.005 
Barrett EP, Joyner LG, Halenda PP (1951) The determination of pore volume and area distributions in porous substances. I. Computations from nitrogen isotherms. J Am Chem Soc 73(1):373-380. https ://doi.org/10.1021/ja01145a126

Bengtsson M, Oksman K (2006) Silane crosslinked wood plastic composites: processing and properties. Compos Sci Technol 66(13):2177-2186. https://doi.org/10.1016/j.compscitech.2005.12.009

Bisanda ETN, Ansell MP (1991) The effect of silane treatment on the mechanical and physical properties of sisal-epoxy composites. Compos Sci Technol 41(2):165-178. https://doi.org/10.1016/02663538(91)90026-L

Björdal CG (2012) Microbial degradation of waterlogged archaeological wood. J Cult Herit 13(3):S118S122. https://doi.org/10.1016/j.culher.2012.02.003

Björdal CG, Nilsson T, Daniel G (1999) Microbial decay of waterlogged archaeological wood found in Sweden applicable to archaeology and conservation. Int Biodeterior Biodegrad 43(1-2):63-73. https://doi.org/10.1016/S0964-8305(98)00070-5

Bjurhager I, Ljungdahl J, Wallström L, Gamstedt EK, Berglund LA (2010) Towards improved understanding of PEG-impregnated waterlogged archaeological wood: a model study on recent oak. Holzforschung 64(2):243-250. https://doi.org/10.1515/hf.2010.024

Blanchette RA (2000) A review of microbial deterioration found in archaeological wood from different environments. Int Biodeterior Biodegrad 46(3):189204. https://doi.org/10.1016/S0964 $-8305(00) 00077-9$

Blanchette RA (2010) Microbial degradation of wood from aquatic and terrestrial environments. In: Mitchell R, McNamara CJ (eds) Cultural heritage microbiology. Fundamental studies in conservation science. ASM Press, Washington, pp 179-218

Borrega M, Kärenlampi PP (2011) Cell wall porosity in Norway spruce wood as affected by high-temperature drying. Wood Fiber Sci 43(2):206-214

Broda M, Frankowski M (2017) Determination of the content of selected elements in medieval waterlogged oak wood from the Lednica Lake-a case study. Environ Sci Pollut Res 24(29):2340123410. https://doi.org/10.1007/s11356-017-9972-7

Broda M, Mazela B (2017) Application of methyltrimethoxysilane to increase dimensional stability of waterlogged wood. J Cult Herit 25:149-156. https://doi.org/10.1016/j.culher.2017.01.007

Broda M, Popescu CM (2019) Natural decay of archaeological oak wood versus artificial degradation processes-an FT-IR spectroscopy and X-ray diffraction study. Spectrochim Acta A 209:280-287. https://doi.org/10.1016/j.saa.2018.10.057

Broda M, Majka J, Olek W, Mazela B (2018) Dimensional stability and hygroscopic properties of waterlogged wood treated with alkoxysilanes. Int Biodeterior Biodegrad 133:34-41. https://doi. org/10.1016/j.ibiod.2018.06.007

Broda M, Mazela B, Dutkiewicz A (2019a) Organosilicon compounds with various active groups as consolidants for the preservation of waterlogged archaeological wood. J Cult Herit 35:123-128. https:// doi.org/10.1016/j.culher.2018.06.006

Broda M, Mazela B, Radka K (2019b) Methyltrimethoxysilane as a stabilising agent for archaeological waterlogged wood differing in the degree of degradation. J Cult Herit 35:129-139. https://doi. org/10.1016/j.culher.2018.06.004

Brunauer S, Emmett PH, Teller E (1938) Adsorption of gases in multimolecular layers. J Am Chem Soc 60(2):309-319. https://doi.org/10.1021/ja01269a023

Burr HK, Stamm AJ (1956) Diffusion in wood. USDA Forest Products Laboratory report 1674. Forest Products Laboratory, Madison, Wisconsin

Cook C, Grattan DW (1990) A method of calculating the concentration of PEG for freeze-drying waterlogged wood. In: Hoffmann P (eds) Proceedings of the 4th ICOM-Group on wet organic archaeological materials conference, pp 239-252

Curling SF, Clausen CA, Winandy JE (2002) Relationships between mechanical properties, weight loss, and chemical composition of wood during incipient brown-rot decay (solid wood products). For Prod J 52(7/8):34-39

Daniel G (2014) Fungal and bacterial biodegradation: white rots, brown rots, soft rots, and bacteria. In: Deterioration and protection of sustainable biomaterials. ACS symposium series. American Chemical Society, Washington, DC, pp 23-54

De Vetter L, Van den Bulcke J, Van Acker J (2010) Impact of organosilicon treatments on the wood-water relationship of solid wood. Holzforschung 64(4):463-468. https://doi.org/10.1515/hf.2010.069

Donath S, Militz H, Mai C (2004) Wood modification with alkoxysilanes. Wood Sci Technol 38(7):555566. https://doi.org/10.1007/s00226-004-0257-1 
Donath S, Militz H, Mai C (2006a) Creating water-repellent effects on wood by treatment with silanes. Holzforschung 60(1):40-46. https://doi.org/10.1515/HF.2006.008

Donath S, Militz H, Mai C (2006b) Treatment of wood with aminofunctional silanes for protection against wood destroying fungi. Holzforschung 60(2):210-216. https://doi.org/10.1515/HF.2006.035

Engelund ET, Thygesen LG, Svensson S, Hill CA (2013) A critical discussion of the physics of woodwater interactions. Wood Sci Technol 47(1):141-161. https://doi.org/10.1007/s00226-012-0514-7

Esteban LG, de Palacios P, Fernández FG, Martín JA, Génova M, Fernández-Golfín JI (2009) Sorption and thermodynamic properties of buried juvenile Pinus sylvestris L. wood aged 1,170 $440 \mathrm{BP}$. Wood Sci Technol 43(7-8):679-690. https://doi.org/10.1007/s00226-009-0261-6

Esteban LG, De Palacios P, Fernández FG, García-Amorena I (2010) Effects of burial of Quercus spp. wood aged $5910 \pm 250 \mathrm{BP}$ on sorption and thermodynamic properties. Int Biodeterior Biodegrad 64(5):371-377. https://doi.org/10.1016/j.ibiod.2010.01.010

Fengel D, Wegener G (1984) Wood. Chemistry, ultrastructure, reactions. De Gruyter, Berlin

Flournoy DS, Kirk TK, Highley TL (1991) Wood decay by brown-rot fungi: changes in pore structure and cell wall volume. Holzforschung Int J Biol Chem Phys Technol Wood 45(5):383-388. https ://doi.org/10.1515/hfsg.1991.45.5.383

Giudice CA, Canosa G (2017) Flame-retardant systems based on alkoxysilanes for wood protection. In: Wood in civil engineering. InTech. https://doi.org/10.5772/64916

Glass SV, Boardman CR, Zelinka SL (2017) Short hold times in dynamic vapor sorption measurements mischaracterize the equilibrium moisture content of wood. Wood Sci Technol 51(2):243260. https://doi.org/10.1007/s00226-016-0883-4

Grattan DW (1982) A practical comparative study of several treatments for waterlogged wood. Stud Conserv 27(3):124-136. https://doi.org/10.1179/sic.1982.27.3.124

Grönqvist S, Hakala TK, Kamppuri T, Vehviläinen M, Hänninen T, Liitiä T, Maloney T, Suurnäkki A (2014) Fibre porosity development of dissolving pulp during mechanical and enzymatic processing. Cellulose 21(5):3667-3676. https://doi.org/10.1007/s10570-014-0352-X

Guo J, Zhou H, Stevanic JS, Dong M, Yu M, Salmén L, Yin Y (2018) Effects of ageing on the cell wall and its hygroscopicity of wood in ancient timber construction. Wood Sci Technol 52(1):131-147. https://doi.org/10.1007/s00226-017-0956-z

Hafezi SM, Enayati A, Hosseini KD, Tarmian A, Mirshokraii SA (2016) Use of amino silane coupling agent to improve physical and mechanical properties of UF-bonded wheat straw (Triticum aestivum L.) poplar wood particleboard. J For Res 27(2):427-431. https://doi.org/10.1007/s1167 6-015-0135-8

Hale MDC, Eaton RA (1986) Soft rot cavity widening: a kinetic approach. Proc R Soc Lond B 227(1247):217-226. https://doi.org/10.1098/rspb.1986.0020

Hill CA (2006) Wood modification: chemical, thermal and other processes, vol 5. Wiley, Chichester

Hill CA (2008) The reduction in the fibre saturation point of wood due to chemical modification using anhydride reagents: a reappraisal. Holzforschung 62(4):423-428. https://doi.org/10.1515/ HF.2008.078

Hill CA, Papadopoulos AN (2001) A review of methods used to determine the size of the cell wall microvoids of wood. J Inst Wood Sci 15(6; ISSU 90):337-345. https://doi.org/10.1007/s0022 6-010-0305-y

Hill CA, Farahani MM, Hale MD (2004) The use of organo alkoxysilane coupling agents for wood preservation. Holzforschung 58(3):316-325. https://doi.org/10.1515/HF.2004.049

Hill CA, Norton A, Newman G (2009) The water vapor sorption behavior of natural fibers. J Appl Polym Sci 112(3):1524-1537. https://doi.org/10.1002/app.29725

Hill CAS, Norton AJ, Newman G (2010) The water vapour sorption properties of Sitka spruce determined using a dynamic vapour sorption apparatus. Wood Sci Technol 44(3):497-514

Hill CA, Keating BA, Jalaludin Z, Mahrdt E (2012a) A rheological description of the water vapour sorption kinetics behaviour of wood invoking a model using a canonical assembly of KelvinVoigt elements and a possible link with sorption hysteresis. Holzforschung 66(1):35-47. https:// doi.org/10.1515/HF.2011.115

Hill CA, Ramsay J, Keating B, Laine K, Rautkari L, Hughes M, Constant B (2012b) The water vapour sorption properties of thermally modified and densified wood. J Mater Sci 47(7):3191-3197. https://doi.org/10.1007/s10853-011-6154-8

Hoffmann P (1986) On the stabilization of waterlogged Oakwood with PEG. II. Designing a twostep treatment for multiquality timbers. Stud Conserv 31(3):103-113. https://doi.org/10.1179/ sic.1986.31.3.103 
Hoffmann P, Jones MA (1990) Structure and degradation process for waterlogged archaeological wood. Adv Chem Ser 225:35-65

Hofstetter K, Hinterstoisser B, Salmén L (2006) Moisture uptake in native cellulose-the roles of different hydrogen bonds: a dynamic FT-IR study using deuterium exchange. Cellulose 13(2):131145. https://doi.org/10.1007/s10570-006-9055-2

Jalaludin Z, Hill CA, Xie Y, Samsi HW, Husain H, Awang K, Curling SF (2010) Analysis of the water vapour sorption isotherms of thermally modified acacia and sesendok. Wood Mat Sci Eng 5(3-4):194-203. https://doi.org/10.1080/17480272.2010.503940

Kang KY, Hwang KR, Park JY, Lee JP, Kim JS, Lee JS (2018) Critical point drying: an effective drying method for direct measurement of the surface area of a pretreated cellulosic biomass. Polymers 10(6):676. https://doi.org/10.3390/polym10060676

Kartal SN, Yoshimura T, Imamura Y (2009) Modification of wood with Si compounds to limit boron leaching from treated wood and to increase termite and decay resistance. Int Biodeterior Biodegrad 63(2):187-190. https://doi.org/10.1016/j.ibiod.2008.08.006

Keating BA, Hill CA, Sun D, English R, Davies P, McCue C (2013) The water vapor sorption behavior of a galactomannan cellulose nanocomposite film analyzed using parallel exponential kinetics and the Kelvin-Voigt viscoelastic model. J Appl Polym Sci 129(4):2352-2359. https://doi.org/10.1002/ app.39132

Kollmann F, Cote WA (1968) Principles of wood science and technology. I solid wood. Springer, New York

Ljungdahl J, Berglund LA (2007) Transverse mechanical behaviour and moisture absorption of waterlogged archaeological wood from the Vasa ship. Holzforschung 61(3):279-284. https://doi. org/10.1515/HF.2007.048

Luo X, Zhu JY (2011) Effects of drying-induced fiber hornification on enzymatic saccharification of lignocelluloses. Enzyme Microb Technol 48(1):92-99. https://doi.org/10.1016/j.enzmi ctec.2010.09.014

Mai C, Militz H (2004) Modification of wood with silicon compounds. Treatment systems based on organic silicon compounds-a review. Wood Sci Technol 37(6):453-461. https://doi.org/10.1007/ s00226-004-0225-9

Mortensen MN, Egsgaard H, Hvilsted S, Shashoua Y, Glastrup J (2007) Characterisation of the polyethylene glycol impregnation of the Swedish warship Vasa and one of the Danish Skuldelev Viking ships. J Archaeol Sci 34(8):1211-1218. https://doi.org/10.1016/j.jas.2006.10.012

Nicholas DD (1973) Wood deterioration and its prevention by preservative treatments: degradation and protection of wood, vol 1. Syracuse University Press, Syracuse

Ormondroyd GA, Curling SF, Mansour E, Hill CA (2017a) The water vapour sorption characteristics and kinetics of different wool types. J Text Inst 108(7):1198-1210. https://doi.org/10.1080/00405 000.2016 .1224442

Ormondroyd GA, Källbom SK, Curling SF, Stefanowski BK, Segerholm BK, Wålinder MEP, Jones D (2017b) Water sorption, surface structure and surface energy characteristics of wood composite fibres refined at different pressures. Wood Mat Sci Eng 12(4):203-210. https://doi. org/10.1080/17480272.2016.1150343

Panov D, Terziev N (2009) Study on some alkoxysilanes used for hydrophobation and protection of wood against decay. Int Biodeterior Biodegrad 63(4):456-461. https://doi.org/10.1016/j.ibiod.2008.12.003

Papadopoulos AN, Hill CAS, Gkaraveli A (2003) Determination of surface area and pore volume of holocellulose and chemically modified wood flour using the nitrogen adsorption technique. Holz Roh Werkst 61(6):453-456. https://doi.org/10.1007/s00107-003-0430-5

Park S, Venditti RA, Jameel H, Pawlak JJ (2006) Changes in pore size distribution during the drying of cellulose fibers as measured by differential scanning calorimetry. Carbohydr Polym 66(1):97-103. https://doi.org/10.1016/j.carbpol.2006.02.026

Pfriem A, Zauer M, Wagenführ A (2009) Alteration of the pore structure of spruce (Picea abies (L.) Karst.) and maple (Acer pseudoplatanus L.) due to thermal treatment as determined by helium pycnometry and mercury porosimetry. Holzforschung 63:94-98. https://doi.org/10.1515/HF.2009.027

Plötze M, Niemz P (2011) Porosity and pore size distribution of different wood types as determined by mercury intrusion porosimetry. Eur J Wood Prod 69(4):649-657. https://doi.org/10.1007/s0010 7-010-0504-0

Popescu CM, Hill CA (2013) The water vapour adsorption-desorption behaviour of naturally aged Tilia cordata Mill. wood. Polym Degrad Stab 98(9):1804-1813. https://doi.org/10.1016/j.polymdegra dstab.2013.05.021 
Popescu CM, Hill CA, Curling S, Ormondroyd G, Xie Y (2014) The water vapour sorption behaviour of acetylated birch wood: how acetylation affects the sorption isotherm and accessible hydroxyl content. J Mater Sci 49(5):2362-2371. https://doi.org/10.1007/s10853-013-7937-x

Rowell RM (ed) (2012) Handbook of wood chemistry and wood composites, 2nd edn. CRC Press, Boca Raton FL

Schniewind AP (1990) Physical and mechanical properties of archaeological wood. In: Rowell RM, Barbour RJ (eds) Archaeological wood. Advances in chemistry series 225. American Chemical Society, Washington, pp 87-109

Singh AP (2012) A review of microbial decay types found in wooden objects of cultural heritage recovered from buried and waterlogged environments. J Cult Herit 13(3):S16-S20. https://doi. org/10.1016/j.culher.2012.04.002

Singh AP, Kim YS, Singh T (2016) Bacterial degradation of wood. In: Kim YS, Funada R, Singh AP (eds) Secondary xylem biology. Academic Press, Cambridge, pp 169-190

Skaar C (1984) Wood-water relationships. In: Rowell R (ed) The chemistry of solid wood. Advances in chemistry. American Chemical Society, Washington

Skaar C (1988) Hygroexpansion in wood. In: Skaar C (ed) Wood-water relations. Springer series in wood science. Springer, Berlin. https://doi.org/10.1007/978-3-642-73683-4_4

Smulski S, Cote WA (1984) Penetration of wood by a water-borne alkyd resin. Wood Sci Technol 18(1):59-75. https://doi.org/10.1007/BF00632131

Stone JE, Scallan AM (1965) Effect of component removal upon the porous structure of the cell wall of wood. J Polym Sci Part C Polym Symp 11(1):13-25. https://doi.org/10.1002/polc.5070110104

Stone JE, Scallan AM (1968) The effect of component removal upon the porous structure of the cell wall of wood. III. A comparison between the Sulfite and Kraft processes. Pulp Pap Mag Can 69(12):69-74

Vorobyev A, Almkvist G, van Dijk NP, Gamstedt EK (2017) Relations of density, polyethylene glycol treatment and moisture content with stiffness properties of Vasa oak samples. Holzforschung 71(4):327-335. https://doi.org/10.1515/hf-2016-0202

Weatherwax RC, Caulfield DF (1971) Cellulose aerogels: an improved method for preparing a highly expanded form of dry cellulose. Tappi J 54(6):985-986

Westermarck S (2000) Use of mercury porosimetry and nitrogen adsorption in characterisation of the pore structure of mannitol and microcrystalline cellulose powders, granules and tablets. Academic Dissertation, University of Helsinki, Helsinki, Finland

Xie Y, Hill CA, Sun D, Jalaludin Z, Wang Q, Mai C (2011a) Effects of dynamic aging (hydrolysis and condensation) behaviour of organofunctional silanes in the aqueous solution on their penetrability into the cell walls of wood. BioResources 6(3):2323-2339

Xie Y, Hill CA, Xiao Z, Mai C, Militz H (2011b) Dynamic water vapour sorption properties of wood treated with glutaraldehyde. Wood Sci Technol 45(1):49-61. https://doi.org/10.1007/s0022 6-010-0311-0

Yin J, Song K, Lu Y, Zhao G, Yin Y (2015) Comparison of changes in micropores and mesopores in the wood cell walls of sapwood and heartwood. Wood Sci Technol 49(5):987-1001. https://doi. org/10.1007/s00226-015-0741-9

Zauer M, Kretzschmar J, Großmann L, Pfriem A, Wagenführ A (2014) Analysis of the pore-size distribution and fiber saturation point of native and thermally modified wood using differential scanning calorimetry. Wood Sci Technol 48(1):177-193. https://doi.org/10.1007/s00226-013-0597-9

Zelinka SL, Glass SV, Jakes JE, Stone DS (2016) A solution thermodynamics definition of the fiber saturation point and the derivation of a wood-water phase (state) diagram. Wood Sci Technol 50(3):443-462. https://doi.org/10.1007/s00226-015-0788-7

Publisher's Note Springer Nature remains neutral with regard to jurisdictional claims in published maps and institutional affiliations. 